\title{
Effect of Disciplinary Duty and Career Development on The Task Commitment With The Motivation to Work As a Variable Intervening the Directorate of Police Air Police In West Sumatera Region
}

\author{
Rizal Sriwijaya ${ }^{1}$, Ibadus Soim², Adril Muniza ${ }^{3}$, Yulina Eliza ${ }^{4}$ \\ Sekolah Tinggi Ilmu Ekonomi “KBP” Jl. Khatib Sulaiman No. 61 Padang \\ Correspondence email: yulinaeliza@akbpstie.ac.id
}

\begin{abstract}
This research aims to be aware of the Influence of task discipline and career development on the task commitment with the motivation to work as variable Intervening members of the Directorate of Police Air West Sumatera region as much as 91 people. Data collected through the dissemination of questionnaires to all populations that can be used for analysis purposes. Testing the hypothesis is done using data analysis technology through Path Anlysis. The results of Data analysis demonstrated that the task discipline and career development have significant effect on the task commitment next task discipline and career development have significant effect on work motivation as variable Intervening. Likewise, the work motivation also has significant effect on the task commitment. Variable Intervening motivation work is significant to the commitment of the task, further motivation work as a intervening between task discipline and task commitment, and motivation to work as a intervening relationship between career development and Task Commitment of the Directorate of West Sumatera Regional police. The magnitude of the influence of duty discipline, career development and work motivation affects the task commitment of 86.4\%, while the remainder (100\%$86.4 \%=13.6 \%$ ) is not included in this model.
\end{abstract}

Keywords : Discipline Tasks; Career Development; Work Motivation; Task Commitment.

\section{Introduction}

Ditpolair which is an element of the principal task of regional police Chief (Kapolda), has a duty to perform the task in the field of water organized by Polda, as stipulated in the regulation of the head of State Police No. 22 year 2010 Article 6 letter (f). The director of the Water Police (Ditpolair) led by the Directorate of Water Police (Dirpolair) responsible to the Kapolda, and in its daily execution, was held under the control of the deputy Chief of regional Police (Wakapolda). In carrying out its duties, Dirpolair was assisted by deputy Director of Water Police (Wadirpolair) who was responsible to Dirpolair. As the same activity as the Directorate of Police of the Republic of Indonesia, Ditpolair Polda West Sumatera, against the burden of fundamental tasks and functions as stated above, then the disciplinary factor to perform the task is Very important factor the above objectives will not be realized if it is not done with high dedication, discipline and professionalism of the police members themselves to try to do the tasks that are charged to him with Good and responsible. Based on the importance of discipline for police members as law enforcement, the Government has published legislation that specifically regulates the discipline of police members, namely government Regulation No. 2 year 2003 about Disciplinary regulation of the Indonesian National Police.

In the fact that lately there are two dilemma issues that are the main basis in this research: low-dissipated work from most of the officers who served on members of Ditpolair West Sumatran Polda. Some types of Such violations in general are late coming into the office, coming home not in time, and present without description so far is often considered to be a thing that is not so important by the members. On the other hand, with the severity of the task, it is very influential. As in certain precarious conditions that need precise handling, fast and accurate for the handling of an incident, the member is not located, and it is further difficult to communicate with them due to the inactive mobile phone, and others, the discipline of entering office and the activities of the morning Apple, very important. The phenomenon of discipline of the task faced by the state of the Ditpolair members of West Sumatra province the task discipline organization is that these two conditions require organizations to find it difficult to work, on one side the organization is required to succeed To carry out activities that are more determined by the professional people of the Labor displinator, and on the other hand the organization is obliged to enforce the rules of discipline and routine work, and on the other hand there are people who are disciplined High but apparently they are not professionals in carrying out the task.

Through the results of initial survey, this condition occurs many times and encountered in the members of Ditpolair Sumatera Baratdue to the existence of the condition that has been culture from the past until now with the condition: (1) Members who offend the rules of discipline, Turned out to have a Skill, high professional in implementing work Auth, where their average is successful in working. On the other hand, they commit violations of the highest work in the month. (2) Members of the Ditpolair district of West Sumatera province which apparently 
Rizal Sriwijaya et al, Effect of Disciplinary Duty and Career Development on The Task Commitment With The Motivation to Work As a Variable Intervening the Directorate of Police Air Police In West Sumatera Region

adhere to the discipline are those who have not been professional in carrying out their duties, and have no skills and Discipline tasks in working of the task field. Meaning they have no effect on the success of achieving task commitments

\section{Methods}

This research is conducted with a quantitative approach with the ex post facto research type, a study aimed at analyzing the influence of Exogenous variables (causes), namely the discipline of the task, career development and work motivation, Endogenous variable, the task commitment. The samples in this study were as many as 91 people were taken based on employee work section. Technical Data analysis using path analysis. According to Ghozali (2013), a pathway analysis is the use of a regression analysis to assess causality relationships between variables (causal models) predetermined by theory.

\section{Results and Discussion}

\section{Line Model I}

Multiple linear regression analyses are used in this study for the purpose of knowing there is no free variable influence on the bound variables.

Table 1

Summary of testing results of multiple regression analysis influence task discipline and career development on task commitments

\begin{tabular}{clrr}
\hline Dependent Variabel & \multicolumn{1}{c}{ Independent Variabel } & Beta & Significance \\
\hline Task Commitment (Y) & Constant & 1,305 & 0,000 \\
& Discipline Tasks (X.1) & 0,026 & 0,003 \\
& Career development (X.2) & 0,385 & 0,000 \\
& $\mathrm{~F}$ & 274,30 & 0,000 \\
& $\mathrm{R}^{2}$ & & 0,445 \\
\hline
\end{tabular}

Data Source: Data Processing results

According to the table above, it is derived that the significance of variability $(\mathrm{X} 1)=0.003<0.05$, this means that Bahwadisiplin has a significant effect on the motivation of work $(\mathrm{Y})$. While career development variables $(\mathrm{X} 2)=$ $0.000<0.05$ mean career development (X2) It significantly affects the task commitment (Y). Whereas the R2 (R Square) value contained in the Model Summary table is 0.445 which means that the constriction of the X1 and X2 variables against $\mathrm{Y}$ is $44.5 \%$ and the remaining $55.5 \%$ is the constriction of other variables that are not included in the study. And from the value of R2 (R Square), obtained e1 by way e1 $=\sqrt{ }(1-0.445)=0.7449$

Based on the results above then obtained structural equations are:

$\mathrm{Y}=0,026 \cdot \mathrm{X}_{1}+0,385 \cdot \mathrm{X}_{2}+0,7449$,

This Model is significant because $\mathrm{p}$ value $=0.000$, smaller than $\alpha 0.05$. From the above data processing, can be obtained Model line Diagram I, as follows:

Figure 1

Model I - line Analysis

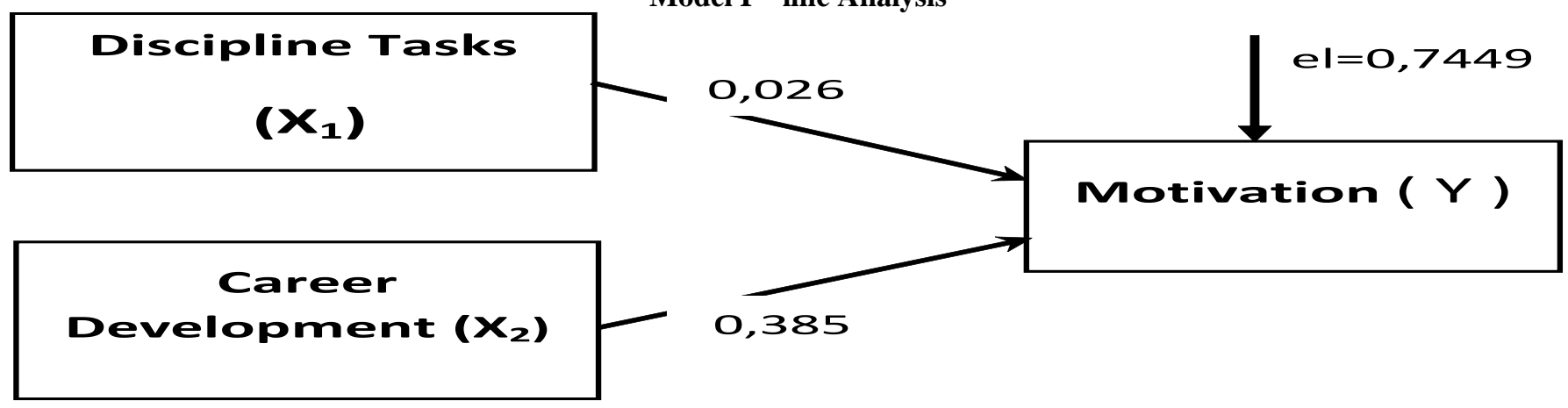

\section{Line Model II}

Multiple linear regression analyses are still used in subsequent studies to obtain the model two coefficient of pathway, this is for the purpose of knowing the presence of free variable influences (discipline and career development) and variables Intervening (motivation) to bound variables (task commitments). You can see the following table 2: 
Rizal Sriwijaya et al, Effect of Disciplinary Duty and Career Development on The Task Commitment With The Motivation to Work As a Variable Intervening the Directorate of Police Air Police In West Sumatera Region

Table 2

Summary of testing results multiple regression analysis influence discipline Assignmentsand career development on task commitments

\begin{tabular}{clrr}
\hline Dependent Variabel & \multicolumn{1}{c}{ Independent Variabel } & Beta & Significance \\
\hline Performance (Y) & Constant & 0,198 & 0,023 \\
& Discipline Task (X.1) & 0,032 & 0,000 \\
& Carrer Developent (X.2) & 0,598 & 0,000 \\
& Motivation work (M) & 0,067 & 0,025 \\
& $\mathrm{~F}$ & & 0,864 \\
\hline
\end{tabular}

Data Source: Data Processing results

The third sign value of the variable is working $(\mathrm{X} 1)=0.000<0.05$. This means that the task $(\mathrm{X} 1)$ has significant effect on the task Commitment $(Z)$. While career development variables $(X 2)=0.000=<0.05$ mean career development (X2) It significantly affects the task commitment $(\mathrm{Z})$. And for work motivation variables $(\mathrm{Y})=0.025<$ 0.05 which means a significant effect on the task Commitment (Z). As well as for the value of R2 (R Square) contained in the Model Summary table is 0.864 which gives the meaning that the variable contribution of X1, X2 and Y against $\mathrm{Z}$ is $86.4 \%$ and the remaining $13.6 \%$ is the contribution of other variables that are not included in the research. And from the $\mathrm{R} 2(\mathrm{R}$ Square) value, obtained e2 by way e $2=\sqrt{ }(1-0.864)=0.3687$

Based on the results above then obtained structural equations are:

$Z=0,032 \cdot X_{1}+0,598 \cdot X_{2}+0,067 \cdot Y+0,3687$

This model is significant because $\mathrm{p}$ value $=0.023$, smaller than $\alpha 0.05$ from above data processing then can be obtained Model II line chart, as follows:

Figure 2.

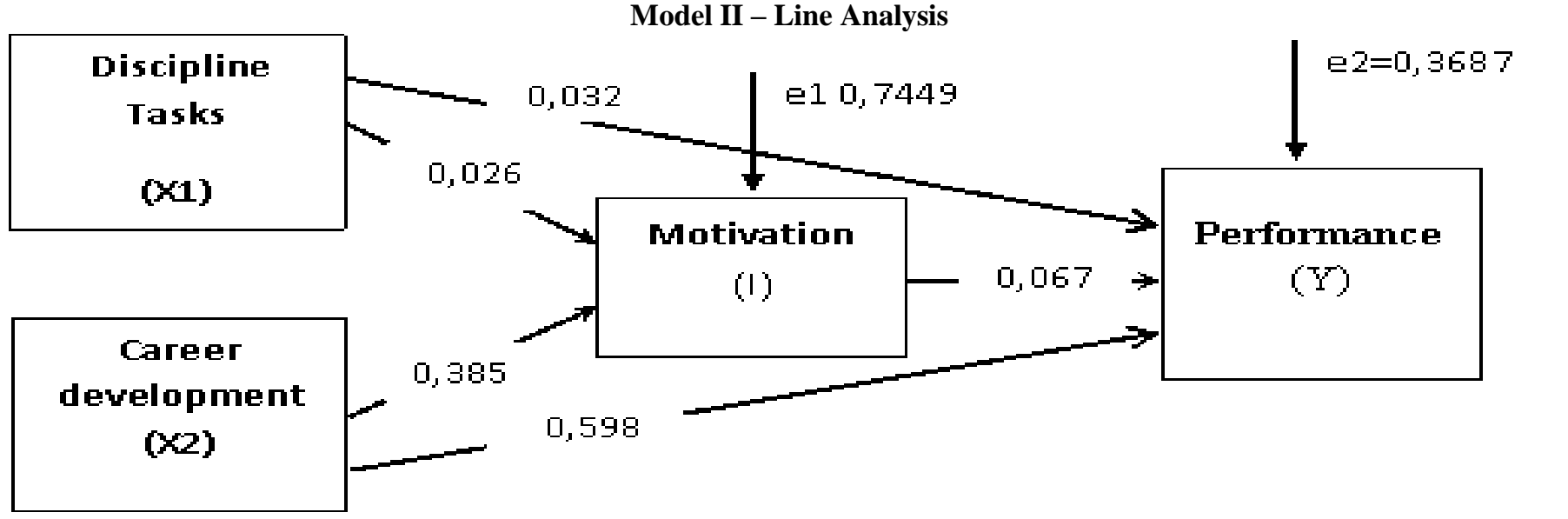

This section contains the discussion on the influence of each of the task discipline (X1) Variables and career development (X2) on the level of duty commitment of the members of the West Sumatran Poda police

\section{Discipline assignments, Career development on task commitments}

In connection with the hypothesis that has been developed in Manadisiplin Tugasdan career development has significant effect on the task commitment of the Indonesian pod of West Sumatera Police,. Statistical analysis Results using Multiple regression shows that both variables are free-discipline assignments (X1) and career development (X2) that have a significant influence on the level of task commitment of the members of the Poda Directorate of West Sumatra police. The results of this study gave an indication that the task discipline and career development and motivation work is so important in explaining the level of duty commitment for all members of the Directorate of West Sumatera Police. The results of this research are not related to the study or research conducted, Yanuardi (2007) in his thesis titled: Effect of Discipline and career development on employee commitment to the task of agricultural and Holtikutura education Kerinci District, stating that there is a significant influence between task discipline and simultaneous career development, with the discovery of the significance value is below.

\section{The influence of task discipline, career development of work motivation}

With respect to the hypothesis that has been developed in Manadisiplin the task of significant impact on work motivation, and career development also has significant effect on the motivation of work then the results of statistical 
Rizal Sriwijaya et al, Effect of Disciplinary Duty and Career Development on The Task Commitment With The Motivation to Work As a Variable Intervening the Directorate of Police Air Police In West Sumatera Region

analysis using regression Shows that the Embassy has a significant influence on the motivation level of the work of the West Sumatran Poda Police Department. The results of this study provide interpertation that the motivation of work and career development is important in explaining the motivation level of work. The results of this research are relevant with past researchers conducted by: Harnadi in his thesis titled Influence of Discipline Duty and task commitment to the motivation of work of the employees of Batang Hari District transportation, Jambi found that there is a significant influence between task discipline and duty commitment to work motivation to find that there is a direct and positive and simultaneous relationship, with the significance level 0.037 (<0.050), at R Square level 0.673 or $67.3 \%$.

Perception of previous research when compared to research that examines the same research variables and different objects and locations, so in this research, also presents a variable of discipline assignments, career development, and Work motivation as a variable intervening. As stated in this study, indeed strengthened from the results of several previous research results.

\section{Conclusion}

Based on data analysis and interpretation that has been submitted, there can be several conclusions from the results of this research:

1. Based on the age variable it is apparent that the majority of respondents to this study were male genders of 89 people (97.8\%), with the rank of Bintara as many as 72 people $(79.12 \%)$, aged $26-35$ as many as 57 people (62.63\%), educated SMA is 65 people $(71.43 \%)$, and has income above Rp. 3.000.000,-as much as 25 people $(46.3 \%)$

2. Significant disciplinary action on the duty commitment of the members of the West Sumatran Poda Police Directorate. Career development has significant effect on the task commitment of West Sumatran Poda police

3. Task discipline Guruber significant influence on the motivation of work of the members of the West Sumatran Poda Police Department. Career development has significant impact on the work motivation of teachers in West Sumatera Polda. The motivation of work has significant effect on the task commitment of the members of West Sumatera Polda

4. Work motivation as intervening variable gives influence between task discipline and task commitment of the members of the Poda Directorate of West Sumatera Police. Work motivation as intervening variable provides influence between career development and task commitment of the Directorate of West Sumatera Police

5. The magnitude of the influence of task discipline, career development and motivation affects the task commitment of $86,4.9 \%$. While the rest $(100 \%-86.4 \%=13.6 \%)$ Influenced by other variables outside this regression model

\section{References}

Achsani, N.A., O. Holtemöller and H. Sofyan, 2005. Econometrica nd Fuzzy Modelling of Indonesian Money Demand. in: Pavel Cizek, Wolfgang H., and Rafal W. Statistical Tools For Finance and Insurance. Berlin Heidelberg, Germany: Springer-Verlag

Barry, E., Rose, A. \& Wyplosz, C. 1996. Contagious Currency Crises. CEPR Discussion Paper No. 1453.London: Center for Economic Policy Research, August

Charemza, W., Woijciech, \& Deadman, F., Derek. 1992. New Directions in Econometric Practice, England: Edward Elgar

Dornbusch, R. \&Fischer, S. 1980, ExchangeRates and Current Account, American Economic Review,70, 960-971

Enders, Walter., 2004. Applied Econometric Times Series, International Edition, Wiley \& Sons, Incorporated, John

Etzel, B.J. 2003.Financeand Investment Dictionary. Indiano polis, Indiana: Wiley Publishing,Inc.

Eun, Cheol S. dan Sangdal Shim, 1989, International Transmission of Stock Market Movement, Journal of Financial Quantitative Analysis, June, pp. 241-255.

Harris, Richard., \& Sollis, Robert. 2003. Applied Time Series Modelling And Forecasting, England: Wiley.

Kim, S.J. \&Sheen, J. 2001. International Linkages and Macroeconomic News Effects onInterest rate Volatility Australia and The US. Pacific-Basin, Finance Journal, 8:85-113

Kolb, W., Robert, 2011.Financial Contagion the Viral Threat to the Wealth of Nations, New Jersey: Wiley.

Krugman, P. 1999.Balance Sheets, the Transfer Problem, and Financial Crises, International Taxand Public Finance, Springer, 6(4):459-472

Lee, Yi., Hsien., 2012, Contagion inInternational Stock Markets during the Sub Prime Mortgage Crisis, International Journal of Economics and Financial Issues, 2:41-53. Retrieved September 16,2013, from http://www.econjournals.com//

Rijckeghem Bureau of Export Trade Promotion (BETP), Philippine Merchandise Total Trade, 2007-2010, Retrieved May 15, 2013, from http://www.dti.gov.ph/uploads/DownloadableForms

Sims, C. A., 1980, Macroeconomics and reality, Econometrica, 48(1):1-48 
Rizal Sriwijaya et al, Effect of Disciplinary Duty and Career Development on The Task Commitment With The Motivation to Work As a Variable Intervening the Directorate of Police Air Police In West Sumatera Region

Sims,C. A., and Zha, T.1998. Bayesian Methods for Dynamic Multivariate Models, International Economic Review, 39(4):949-968

TheWorld Bank. GDP, Economic Growth, inflation and money supply, export import, net foreign assets. (2005-2011). Retrieved March 5, 2013, from http://data.worldbank.org/

Yang, Tracy. 2002, Crisis, Contagion, and East Asian Stock Markets, Institute of Southeast Asian studies. 